\title{
SITUS-SITUS “TERSEMBUNYI” MASA KLASIK DI KABUPATEN SEMARANG, JAWA TENGAH
}

\section{"HIDDEN" SITES FROM THE CLASSICAL PERIOD IN SEMARANG REGENCY, CENTRAL JAVA}

\author{
Sugeng Riyanto \\ Balai Arkeologi Yogyakarta \\ esge er@yahoo.com
}

\begin{abstract}
Archaeological data of classical period in Semarang Regency has been "underestimated" in archaeological research as an area of Ancient Mataram period because the region is situated "outside" the Kedu - Prambanan axis, except the Gedongsongo and Ngempon temples. It's convinced that in this region the others archaeological data are still covered as well. These sites are still "hidden" and there's a time to be revealed as part of Ancient Mataram civilization. The urge to uncover traces of civilization is manifested in an archaeological survey for acquiring of classical period data in Semarang Regency. This article reflects the results of the survey and has been set in an explanation of "hidden" sites from the classical period in Semarang Regency. This focused on two things, their archaeological potency and also the configuration of space based on its distribution.
\end{abstract}

Keywords : Semarang, Classical Period, Ancient Mataram

\begin{abstract}
ABSTRAK
Data arkeologi masa klasik di Kabupaten Semarang selama ini "kurang diperhitungkan" dalam penelitian arkeologi sebagai wilayah masa Mataram Kuna karena "di luar" poros Kedu - Prambanan, kecuali, mungkin, kompleks candi Gedongsongo dan candi Ngempon. Ada keyakinan bahwa di wilayah ini sebenarnya juga tersimpan data arkeologi masa klasik lainnya. Situs-situs tersebut masih "tersembunyi" dan ada saatnya untuk diungkap sebagai bagian dari buah peradaban masa Mataram Kuna. Dorongan untuk mengungkap jejak-jejak peradaban tersebut diwujudkan dalam sebuah kegiatan survei yang secara khusus di tujukan untuk mendapatkan data arkeologi masa klasik di Kabupaten Semarang yang kurang, jika tidak dapat dikatakan tidak, mendapat perhatian. Artikel ini merupakan refleksi hasil kegiatan tersebut yang dituangkan dalam bentuk paparan situssitus yang "tersembunyi" dari masa klasik yang tersebar di Kabupaten Semarang. Dalam hal ini fokus perhatian dititikberatkan pada dua hal, yaitu potensi masing-masing benda arkeologi atau situs serta konfigurasi ruang berdasarkan sebarannya.
\end{abstract}

Kata kunci: Semarang, Situs Masa Klasik, Mataram Kuna

Tanggal masuk : 13 Februari 2013

Tanggal diterima : 26 April 2013 


\section{PENDAHULUAN}

Masa klasik di Indonesia sering disebut juga dengan masa Hindu-Buddha, yaitu suatu rentang waktu di masa lalu ketika anasir kebudayaan dari India yang diilhami oleh ide-ide dalam agama Hindu dan Buddha sangat menonjol dan cukup kuat dalam peradaban. Secara formal masa klasik sebagai sebuah kajian dalam arkeologi berada pada rentang waktu sekitar abad V - XVI Masehi (Satari 2002, 61). Namun sering tidak disadari bahwa penggunaan istilah "masa Hindu-Buddha" dan "masa Klasik", meskipun menunjuk pada kurun yang sama tetapi memiliki tekanan yang berbeda. Isitilah "masa Hindu-Buddha", tidak dapat dipungkiri lagi, jelas menunjuk pada aspek-aspek budaya yang terkait langsung dengan kerangka latar keagamaan, yaitu pengaruh agama Hindu dan agama Buddha. Isitilah "klasik" sendiri merupakan analogi dari budaya klasik Yunani dan Romawi pada saat mencapai puncak dalam sejarah kesenian mereka, sehingga isitlah "klasik" diartikan berkelas tinggi dan bersifat abadi. Istilah "masa Klasik", harus digarisbawahi lagi, sepenuhnya merujuk pada sejarah seni, yaitu pada saat kesenian Indonesia Kuno mencapai puncaknya sebagaimana ditunjukkan oleh estetika bangunan candi dan arca (Satari 2002, 61). Salah satu periode dalam masa klasik di Indonesia adalah pada saat Mataram Kuna berkuasa, khususnya di wilayah Jawa Tengah.

Kerajaan Mataram Kuna yang berkuasa di Jawa Tengah antara abad VIII sampai dengan $X M$ memang diperkirakan berpusat di poros Kedu-Prambanan (Bosch 1974, 19). Hal ini didasarkan pada banyaknya tinggalan bangunan-bangunan monumental berupa candi-candi yang megah di kawasan itu. Poros KeduPrambanan meliputi daerah-daerah yang termasuk wilayah Kabupaten Magelang Provinsi Jawa Tengah dan Kabupaten Sleman Daerah Istimewa Yogyakarta, khususnya sekitar Prambanan. Di kawasan Kedu terdapat Candi Borobudur, Mendut, Pawon, Ngawen, dan masih banyak candicandi lain di sekelilingnya. Di kawasan sekitar Prambanan terdapat Candi Prambanan (Lorojonggrang), Sewu, Plaosan, Sari, Kalasan, Sambisari, dan candi-candi lainnya. Banyaknya tinggalan candi-candi besar dan megah itu menunjukkan indikasi adanya kota besar pada masa itu. Paling tidak dengan banyaknya bangunan keagamaan tersebut tentu di sekitarnya terdapat komunitas yang menggunakan bangunan itu sebagai sarana ibadahnya.

Dalam hal ini wilayah Kabupaten Semarang memang terkesan berada "di luar" poros tersebut. Data arkeologi masa klasik di Kabupaten Semarang yang sudah dikenal hingga saat ini adalah kompleks candi Gedongsongo di Kecamatan Bandungan, Candi Dukuh di Kecamatan Banyubiru, Candi Ngempon dan Ganesha Sekunir di Kecamatan Bergas, prasasti Ngrawan di Kecamatan Getasan, Yoni Bedono di Kecamatan Jambu, petirtaan Derekan di Kecamatan Pringapus, dan prasasti Plumpungan di Kecamatan Sidorejo (Riyanto 2012). Tidak semua situs tersebut dikenal oleh masyarakat, dan mungkin hanya beberapa peneliti pula yang mengenal seluruh situs tersebut dengan baik karena beberapa di antaranya memang "tersembunyi" dari perhatian. Dari sejumlah situs yang disebutkan, yang paling dikenal oleh masyarakat adalah kompleks candi Gedongsongo, petirtaan Derekan, dan candi Ngempon karena memang sudah dikelola sebagai objek wisata.

Di sisi lain, mengenal situs sebagai sebuah entitas, penting artinya sebagai dasar dalam memandang masa lalu sebagai sebuah konstelasi yang berada di area budaya tertentu. Dalam pandangan tersebut suatu situs ditempatkan sebagai bagian integral dari suatu kesatuan ruang budaya dalam periode atau masa yang kurang lebih sama. Dalam studi arkeologiruang (spatial archaeology) benda arkeologi seperti struktur, bangunan, atau fitur lainnya, serta artefak maupun ekofak, tidak ditempatkan sebagai entitas tetapi sebagai sebaran. Data arkeologi masa klasik di Kabupaten Semarang selama ini "kurang diperhitungkan" dalam penelitian arkeologi sebagai wilayah masa Mataram Kuna karena "di luar" poros Kedu Prambanan, kecuali, mungkin, kompleks candi Gedongsongo dan candi Ngempon. Ada keyakinan bahwa di wilayah ini sebenarnya juga tersimpan data arkeologi 
masa klasik lain di luar delapan situs yang telah disebutkan. Situs-situs tersebut masih "tersembunyi" dan ada saatnya untuk diungkap sebagai bagian dari buah peradaban masa Matarm Kuna.

Dorongan untuk mengungkap jejakjejak peradaban tersebut diwujudkan dalam sebuah kegiatan survei yang secara khusus di tujukan untuk mendapatkan data arkeologi masa klasik di Kabupaten Semarang yang kurang, jika tidak dapat dikatakan tidak, mendapat perhatian. Artikel ini merupakan refleksi hasil kegiatan tersebut yang dituangkan dalam bentuk paparan situs-situs yang "tersembunyi" dari masa klasik yang tersebar di Kabupaten Semarang. Dalam hal ini fokus perhatian dititikberatkan pada dua hal, yaitu potensi masing-masing benda arkeologi atau situs serta konfigurasi ruang berdasarkan sebarannya.

\section{METODE PENELITIAN}

Dalam arkeologi terdapat tiga
dimensi utama dalam kajianya, yaitu
dimensi bentuk, dimensi waktu, dan
dimensi ruang. Dalam perkembangan
disiplin arkeologi, dimensi ruang (spatial)
muncul belakangan dibandingkan dimensi
bentuk (formal) maupun dimensi waktu
(temporal) (Mundardjito 2002, 70).
Pandangan pada ketiga dimensi tersebut
sebenarnya terkait dengan tekanan
perhatiannya terutama dalam hal keruangan, yaitu dari artifact oriented, kemudian site oriented dan akhirnya region oriented. Yang dimaksud dengan isitilah ruang dalam kajian ini mengacu pada aspek keletakan, lokasi, atau tempat ditemukanya benda arkeologi dan situs di permukaan bumi. Dalam wacana arkeologi, hal ini dikenal sebagai konsep in situ (Mundardjito 2002, 71). Lebih kanjut dikatakan oleh Mundardjito bahwa informasi in situ tersebut diperoleh dengan dua cara, yaitu pengamatan langsung di lapangan atau secara tidak langsung, yaitu melalui telaah kepustakaan dan, bahkan, berita lisan. Dalam kerangka kajian ini informasi astronomis atau posisi benda arkeologi dalam posisi lintang - bujur secara global dan rekaman posisi ketinggian dari permukaan laut (three dimensional recording) merupakan informasi yang harus ada dan dapat diperoleh. Dengan demikian maka kita dapat: 1) menempatkan temuan arkeologi pada peta dasar secara tepat (plotting) sebagai bahan analisis (keruangan) yang sahih, 2) menemukan kembali data keletakan benda arkeologi atau situs jika di kemudian hari terjadi perubahan nama tempat penemuan (ibid.). Oleh karena itu cara pengamatan langsung di lapangan merupakan hal terbaik yang dapat dilakukan untuk memperolah kedua informasi tersebut.

Tentu saja kedua jenis rekaman tersebut belum menggambarkan aspek formal karena baru memberikan informasi dalam dimensi keruangan. Oleh karena itu dalam pengamatan lapangan juga diperlukan kegiatan pendeskripsian yang setidaknya meliputi secara verbal, yaitu uraian verbal dan uraian metrik (ukuran) atas benda arkeologi atau situs yang ditemukan, maupun ceara piktorial melalui penggambaran dan fotografi. Namun, di luar itu semua secara teknis pencarian benda arkeologi dan situs ditempuh melalui tiga cara, yaitu: 1) mempelajari sumber-sumber pustaka yang berkaitan dengan keberadaan benda arkeologi dan situs di Kabupaten Semarang, 2) penggalian informasi melalui wawancara dengan warga atau tokoh-tokoh masyarakat, dan 3) eksplorasi dan pengamatan atas gejala-gejala keberadaan benda arkeologi dan situs. Hal-hal lain yang direkam dalam pengamatan lapangan meliputi lokasi administrasi, tanda alami, jenis lahan, pemilik lahan, serta informasi lain yang diperolah dari hasil pengamatan maupun dari warga setempat.

Kerangka dasar penelitian yang dilakukan adalah jenis penelitian deskriptifanalitik dengan penalaran induktif. Dalam metode ini dilakukan analisis berbagai data arkeologi yang ditemukan di Kabupaten Semarang secara deskriptif untuk menjelaskan hal-hal yang berkaitan dengan permasalahan penelitian dan bersifat lebih umum yaitu mengenai keragaman bentuk data dan aspek keruangannya.

Danim (2002, 41) menggambarkan bahwa penelitian deskriptif dimaksudkan untuk mendeskripsikan suatu situasi atau 
area populasi tertentu yang bersifat faktual secara sistematis dan akurat. Pengertian yang sama mengenai penelitian deskriptif antara lain juga dikemukakan oleh Azwar $(1998,5)$ dan Haryono $(1993,10)$ yang pada intinya mengemukakan bahwa penelitian jenis ini bertujuan untuk menggambarkan secara sestematis dan akurat mengenai populasi atau bidang tertentu. Sementara itu, menurut Sumanto $(1995,77)$ penelitian deskriptif analitis berusaha mendeskripsi dan menginterpretasi apa yang ada; dapat mengenai kondisi atau hubungan yang ada. Dalam hal ini, biasanya data dikumpulkan melalui survei, wawancara, atau observasi sebagai fakta empiris.

\section{HASIL PENELITIAN}

\section{Paparan Data}

Hasil survei meliputi 12 lokasi atau titik di antaranya berupa benda arkeologi tunggal, dan lainya merupakan sekumpulan benda-benda arkeologi yang berada pada area tertentu. Data hasil survei selengkapnya dipaparkan berikut ini.

\section{Situs Yoni Kerep}

Secara administratif situs ini terletak di Dusun Kerep, Kelurahan panjang, Kecamatan Ambarawa dalam posisi astronomis S $07^{0} 15^{\prime} 12.5^{\prime \prime}$ dan E $110^{\circ} 23^{\prime}$ 55.1" dan elevasi 584 dpl. Benda arkeologi yang ditemukan berupa sebuah yoni yang berbahan batu andesit. Oleh warga yoni telah disemen pada bagian dasarnya. Yoni kerep berukuran penampang sisi atas 57.5 x $57.5 \mathrm{~cm}$, penampang sisi bawah $60 \times 60$ $\mathrm{cm}$, lubang tengah berbentuk segi empat berukuran $18 \times 18 \mathrm{~cm}$, kedalaman lubang $23 \mathrm{~cm}$. Cerat yoni mempunyai panjang 15 $\mathrm{cm}$, lebar bagian dalam $20 \mathrm{~cm}$, lebar bagian ujung $16 \mathrm{~cm}$. Kondisi yoni relatif utuh namun terkesan terbengkelai, dan sekarang terletak di pinggir jalan desa Panjang.

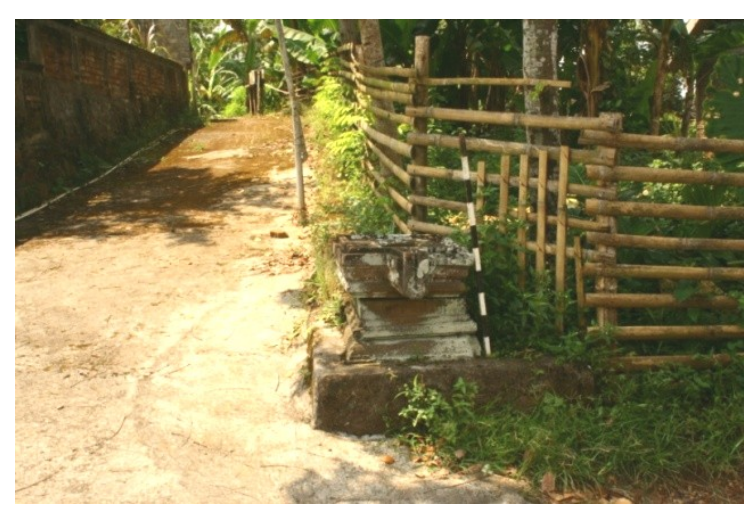

Foto 1. Yoni Kerep

\section{Situs Banyukuning}

Di halaman Mesjid Sa'idi, Dusun Krajan, Desa Banyukuning, Kecamatan Bandungan terdapat dua buah tempayan atau gentong batu, masing-masing terletak di kanan dan kiri pintu masuk mesjid. Gentong batu berada di sebelah kanan pintu masuk ke masjid. Gentong batu terbuat dari batu putih (tuff) dan kondisi masih bagus. Berdiameter bagian atas 56 $\mathrm{cm}$, tinggi $62 \mathrm{~cm}$, kedalaman lubang 43 $\mathrm{cm}$. Gentong batu berada di sebelah kiri pintu masuk ke masjid kondisi terawat. Berbahan batu putih (tuff). Tinggi $52 \mathrm{~cm}$, diameter atas $50 \mathrm{~cm}$, kedalaman lubang 35 $\mathrm{cm}$. Secara astronomis lokasi ini terletak pada S $07^{\circ} 14^{\prime} 19,6^{\prime \prime}$ dan E $110^{\circ} 20^{\prime} 38,9^{\prime \prime}$ dengan ketinggian dari permukaan laut mencapai 912 meter.

Kedua benda arkeologi ini tergolong terawat, antara lain tampak dari adanya pagar pelindung pada masing-masing tempayan. Menurut informasi yang diperoleh dari warga, kedua tempayan berasal dari bagian dalam masjid yang kemudian diletakkan di bagian depan masjid seperti saat ini.

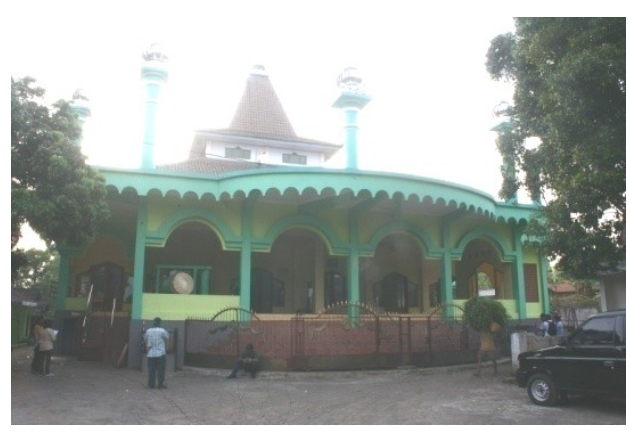

Foto 2. Lokasi penyimpanan gentong batu 


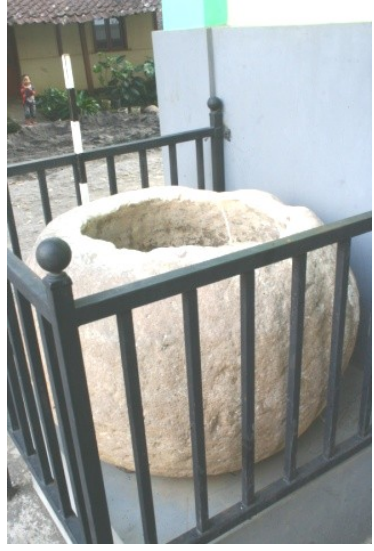

Foto 3. Salah satu Gentong batu

\section{Situs Candi Asu}

Situs Candi Asu terletak di Dusun Candi, Desa Candi, Kecamatan Bandungan dan secara astronomis berada pada $S 07^{\circ} 13^{\prime} 25,9^{\prime \prime}$ dan E $110^{\circ} 20^{\prime} 29,2^{\prime \prime}$ dengan elevasi 1055 meter dpl. Objek arkeologi yang ditemukan di situs meliputi yoni, makara, kemuncak, dan alas kemuncak. Deskripsi masing-masing objek tersebut adalah sebagai berikut.

a. Yoni: bahan batu andesit. Tinggi 61 $\mathrm{cm}$, penampang atas $77 \times 77 \mathrm{~cm}$, penampang bawah $82 \times 82 \mathrm{~cm}$, panjang cerat $25 \mathrm{~cm}$, tinggi cerat 23 $\mathrm{cm}$, diameter depan $19 \mathrm{~cm}$, bagian tengah $19 \times 19 \mathrm{~cm}$, kedalaman lobang tengah $46 \mathrm{~cm}$.

b. Makara, bahan batu andesit, panjang $60 \mathrm{~cm}$, tebal $23 \mathrm{~cm}$, tinggi belakang 37 $\mathrm{cm}$, tinggi depan $47 \mathrm{~cm}$.

c. Kemuncak: bahan batu andesit, tinggi $21 \mathrm{~cm}$, penampang atas $6 \times 6 \mathrm{~cm}$, penampang bawah $19 \times 19 \mathrm{~cm}$.

d. Alas kemuncak: bahan batu andesit, tinggi $38 \mathrm{~cm}$, sisi atas $39 \times 39 \mathrm{~cm}$, penampang tengah $71 \times 75 \mathrm{~cm}$, lobang tengah $21 \times 21 \mathrm{~cm}$, kedalaman lobang $28 \mathrm{~cm}$.

Benda-benda arkeologi tersebut ditempatkan di halaman rumah Bapak Tumpuk dan dilindungi dengan bangunan cungkup terbuka. Menurut informasi, lokasi ini menjadi tempat ziarah dan bersamadi, terutama pada malam Selasa dan Jumat Kliwon, oleh penziarah yang datang dari luar dusun tersebut.

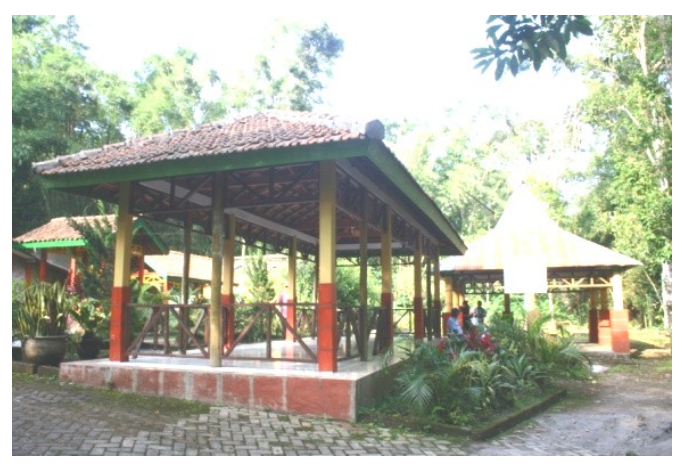

Foto 4. Lokasi Situs Candi Asu

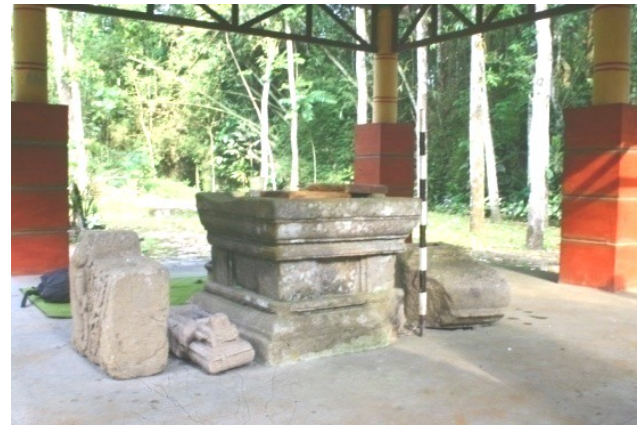

Foto 5. Yoni, Makara, dan Alas Kemuncak di situs Candi Asu

\section{Situs Nglarangan}

Situs terletak di Dusun Nglarangan, Desa Candi, Kecamatan Bandungan, secaran astronomis berada pada $\mathrm{S} 07^{\circ} 13^{\prime}$ $06,3^{\prime \prime}$ dan $\mathrm{E} 110^{\circ} 20^{\prime} 34,6^{\prime \prime}$ dengan elevasi 1137 meter dpl. DI situs ini ditemukan sejumlah objek arkeologi yaitu yoni, kala, bagian kemuncak, dan umpak batu. Kumpulan cagar budaya ini dijumpai pada pos ronda di dusun Nglarangan dan Desa candi. Deskripsi masing-masing objek adalah sebagai berikut.

a. Yoni berbahan batu andesit, berukuran penampang atas $75 \times 75$ $\mathrm{cm}$, tinggi $46 \mathrm{~cm}$. Pada bagian bawah sudah hilang. Panjang cerat $29 \mathrm{~cm}$, lubang tengah $25 \times 25 \mathrm{~cm}$, kedalaman lubang $21 \mathrm{~cm}$.

b. Yoni berbahan andesit, penampang atas $50 \times 50 \mathrm{~cm}$, tinggi $53 \mathrm{~cm}$, panjang cerat $15 \mathrm{~cm}$, lubang tengah $19 \times 19$ $\mathrm{cm}$, kedalaman $8 \mathrm{~cm}$.

c. Umpak berbahan andesit berukuran tinggi $30 \mathrm{~cm}$, penampang atas $27 \times 21$ $\mathrm{cm}$.

d. Kemuncak berbahan andesit, penampang atas $29 \times 29 \mathrm{~cm}$, penampang bawah $48 \times 48 \mathrm{~cm}$, tinggi $28 \mathrm{~cm}$. 
e. Kala berbahan andesit dan hanya tersisa bagian muka. Berukuran tinggi $31 \mathrm{~cm}$, lebar $40 \mathrm{~cm}$, tebal $19 \mathrm{~cm}$.

Benda cagar budaya tersebut berasal dari tegalan yang lokasi agak jauh dari permukiman penduduk. Oleh penduduk dikumpulkan di samping pos ronda dan terkesan terbengkelai.

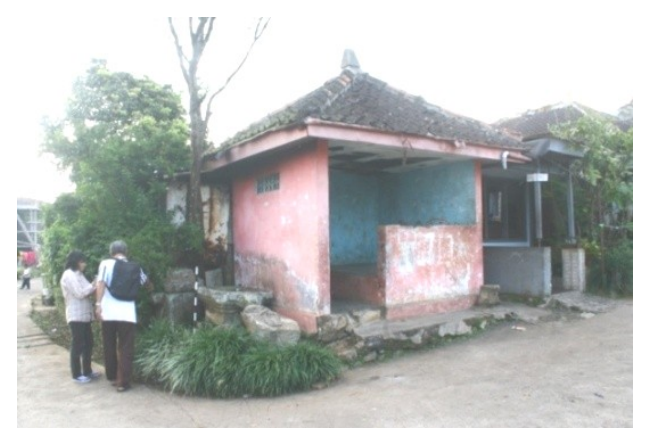

Foto 6. Lokasi Situs Nglarangan

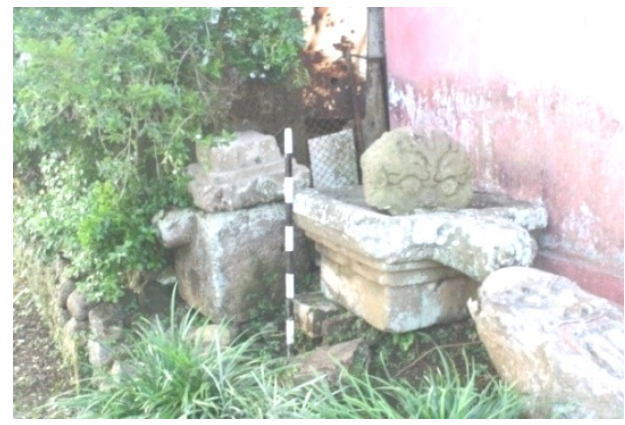

Foto 7. Yoni dan Kala

\section{Situs Umbul Sidomukti}

Situs yang terletak di Dusun Sidomukti, Desa Sidomukti, Kecamatan Bandungan ini menyimpan data arkeologi berupa batu-batu candi dan arca Durga. Secara astronomis lokasi ini berada pada S $07^{0} 11^{\prime} 41.2^{\prime \prime}$ dan E $110^{\circ} 22^{\prime} 27.3^{\prime \prime}$ serta elevasi 1046 meter dari permukaan laut. Deskripsi masing-masing objek arkeologi tersebut adalah sebagai berikut.

a. Arca Durga. Terbuat dari batu andesit, bagian kepala sudah hilang, tinggi arca $44 \mathrm{~cm}$, lebar $24 \mathrm{~cm}$, tebal $2,5 \mathrm{~cm}$

b. Jaladwara. Berjumlah tujuh buah yang terbuat dari batu andesit. Jaladwara terbesar berukuran panjang $60 \mathrm{~cm}$, lebar $19 \mathrm{~cm}$, lebar tepi $4,5 \mathrm{~cm}$, tinggi $16 \mathrm{~cm}$, kedalaman saluran $6 \mathrm{~cm}$.

c. Alas Kemuncak. Terbuat buat dari batu andesit. Kondisi relatif utuh. Berukuran panjang sisi $40 \times 38 \mathrm{~cm}$, tinggi $17 \mathrm{~cm}$, penampang atas berbentuk segi empat bagian tepi berukuran $6 \mathrm{~cm}$, lubang berukuran 13 , $5 \times 13,5 \mathrm{~cm}$ dan kedalaman lubang 2 $\mathrm{cm}$

d. Kemuncak. Terbuat dari batu andesit dan kondisi relatif utuh. Penampang bawah $44 \times 44 \mathrm{~cm}$, penampang atas $26 \mathrm{~cm}$. Tinggi $46 \mathrm{~cm}$, lubang $11 \times 12$ $\mathrm{cm}$, kedalaman lubang $8 \mathrm{~cm}$.

e. Antefiks. Terbuat dari batu andesit dan kondisi relatif utuh. Berukuran tinggi 38, lebar sisi $40 \mathrm{~cm}$, tebal $20 \mathrm{~cm}$

Lokasi situs saat ini merupakan Pondok Wisata Umbul Sidomukti yang dimiliki oleh Bapak Siswono Yudohusodo dan secara manjerial dikelola oleh PT Panorama Agro Sidomukti. Secara umum data arkeologi tersebut terkesan terbengkelai. Menurut informasi kumpulan benda cagar budaya ini berasal dari lokasi sekitar Pondok Wisata Umbul Sidomukti yang diketemukan pada saat pembangunan pondok wisata tersebut. Selain kumpulan batu-batu candi tersebut, masih dijumpai beberapa temuan sejenis yang berada di sekitar lokasi pondok wisata tepatnya pada ladang. Lokasi temuan ini berada pada $S 07^{0} 11^{\prime} 42.0$ " $\mathrm{E}$ $110^{\circ} 22^{\prime} 23.9^{\prime \prime}$

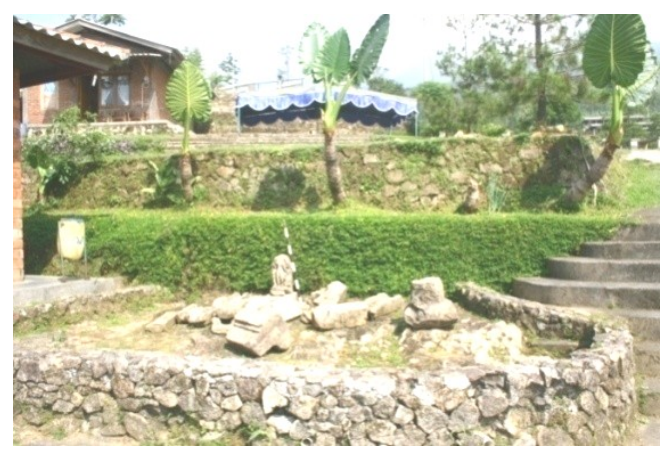

Foto 8. Lokasi Kumpulan beberapa batu candi 


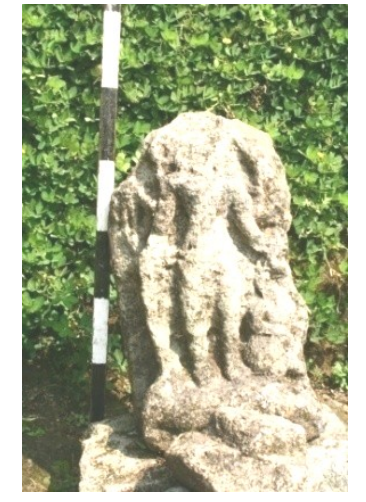

Foto 9. Arca Durga dari Umbul Sidomukti

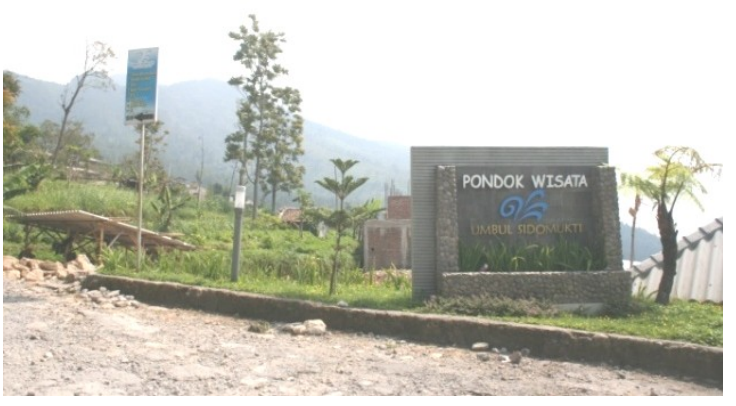

Foto 10. Lokasi temuan beberapa batu candi

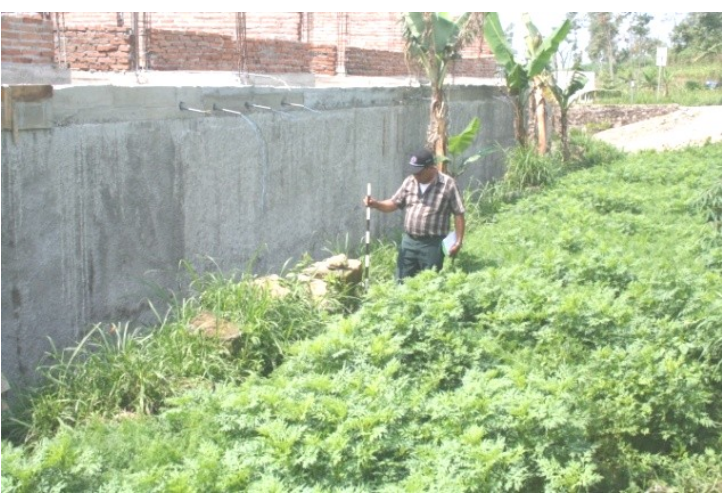

Foto 11. Sebaran batu candi di sekitar Situs Umbul Sidomukti

\section{Situs Pentasan}

Secara astronomis situs Pentasan berada pada S $07^{\circ} 18^{\prime} 24.7^{\prime \prime}$ dan E $110^{\circ}$ 25' 21.7" dengan elevasi 495 meter dpl. Secara administrasi lokasi situs temasuk di dalam wilayah Dusun Pentasan, Desa Kebondowo, Kecamatan Banyubiru. Objek arkeologi yang ditemukan meliputi yoni, lingga, dan umpak. Deskripsi masingmasing objek yang ditemukan di situs Pentasan adalah sebagai berikut.

a. Lingga. Berbahan batu andesit dengan kondisi relatif utuh. Lingga berukuran tinggi $35 \mathrm{~cm}$, tinggi bagian dasar berbentuk segi empat adalah $8 \mathrm{~cm}$ dengan lebar $19 \times 19 \mathrm{~cm}$, dan tinggi bagian lingga yang berbentuk silindris adalah $28 \mathrm{~cm}$ dan berdiameter $17 \mathrm{~cm}$.

b. Yoni. Berbahan batu andesit dan bagian ceratnya sudah hilang. Ukuran penampang bawah $72 \times 72 \mathrm{~cm}$, penampang atas $55 \times 55 \mathrm{~cm}$, tinggi yoni $26 \mathrm{~cm}$.

c. Umpak. Berbahan batu andesit berjumlah dua buah dengan kondisi relatif utuh. Ukuran umpak mempunyai tinggi $20 \mathrm{~cm}$, sisi penampang bawah $20 \times 20 \mathrm{~cm}$, berdiameter $19 \mathrm{~cm}$.

Situs Pentasan berada di lokasi wisata Bukit Cinta, Rawa Pening, dan saat ini berada di dalam sebuah cungkup. Menurut informasi, objek-objek arkeologi yang ada di situs ini merupakan temuan in situ. Lingkungan situs berupa Rawa Pening dan lokasi situs berada di dalam lokasi Wisata Bukit Cinta yang dikelola oleh Pemerintah Kabupaten Semarang. Secara umum situs dan objek arkeologi tergolong terawat dengan bangunan cungkup sebagai pelindung. Pada waktuwaktu tertentu lokasi situs menjadi objek ziarah bagi orang-orang yang datang dari berbagai daerah, khususnya Kabupaten Semarang.

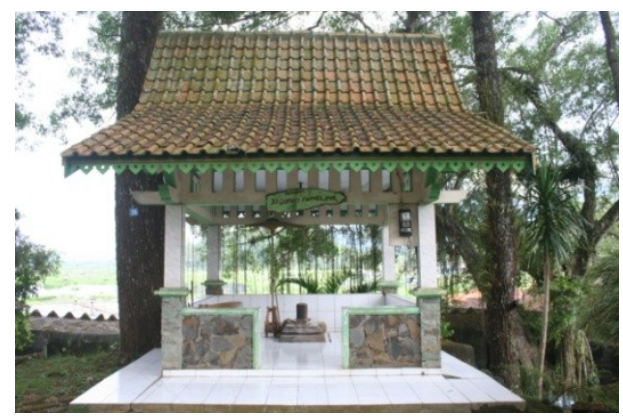

Foto 12. Lokasi Lingga Yoni Pentasan

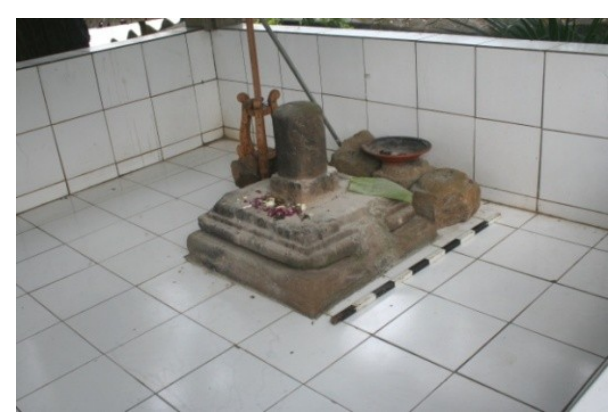

Foto 13. Lingga, Yoni, dan Umpak 


\section{Situs Muncul}

Di situs ini terdapat dua objek arkeologi yaitu yoni dan arca Siwa Mahaguru. Lokasi situs berada di lokasi wisata Pemandian Air Alam Muncul yang secara administrasi berada di Dusun Muncul, Desa Rowoboni, Kecamatan Banyubiru. Secara astronomis lokasi situs berada pada S $07^{\circ} 10^{\prime} 42.9^{\prime \prime}$ dan E $110^{\circ}$ 26' 24.9" serta elevasi 495 meter dpl. Berikut deskripsi tinggalan arkeologi tersebut.

a. Yoni. Terbuat dari bahan batu andesit dengan kondisi bagian cerat sudah hilang. Keberadaan yoni ini berasal dari Umbul Muncul yang sekarang dimanfaatkan sebagai kolam renang. Dimensi yoni mempunyai tinggi $55 \mathrm{~cm}$, lebar sisi atas $53 \times 53 \mathrm{~cm}$ dan sisi bawah $60 \times 60 \mathrm{~cm}$, lubang tengah berbentuk segi empat dengan ukuran $21 \times 21 \mathrm{~cm}$ dengan kedalaman $37 \mathrm{~cm}$

b. Arca Siwa Mahaguru. Terbuat dari bahan batu andesit dengan kondisi setengah badan bagian dada kebawah sudah hilang. Berdasarkan identifikasi atribut trisula, prabha, serta berjenggot diduga tokoh ini adalah Siwa Mahaguru. Dimensi fragmen Siwa Mahaguru mempunyai tinggi $27 \mathrm{~cm}$, lebar $26 \mathrm{~cm}$, dan tebal $15 \mathrm{~cm}$.

Keberadaan objek arkeologi di lokasi Pemandian Air Alam Umbul Muncul yang dikelola oleh Pemerintah Kabupaten Semarang ini terkesan terbengkelai. Kedua objek teronggok di dekat pintu masuk dan jelas sangat rawan dari segi keamanannya.

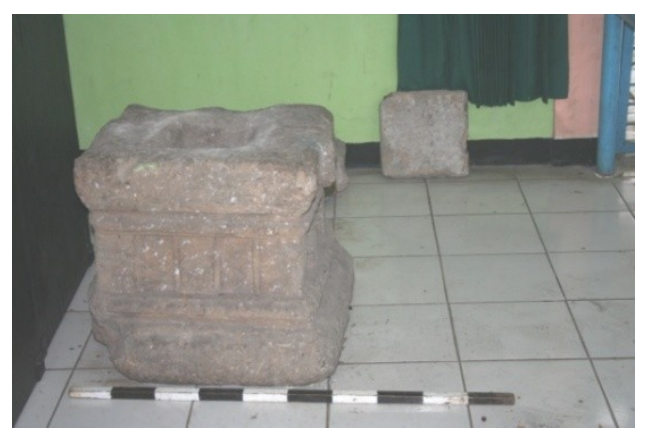

Foto 14. Yoni Muncul

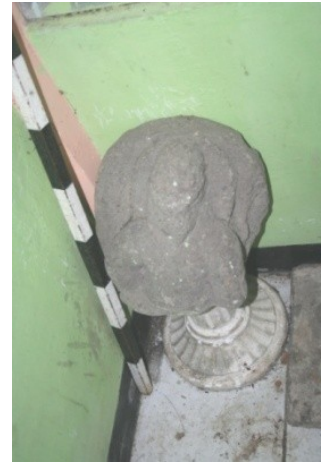

Foto 15. Fragmen Arca Siwa Mahaguru

\section{Situs Randugunting}

Lokasi Situs Randugunting berada di tebing sungai Kalijurangmangu sisi utara, termasuk di dalam wilayah Dusun Utan, Desa Randugunting, Kecamatan Bergas. Secara astronomis lokasi ini berada pada S $07^{\circ} 12^{\prime} 48.3^{\prime \prime}$ dan E $110^{\circ} 25^{\prime} 38.7^{\prime \prime}$, serta elevasi 513 meter dpl. Objek yang ditemukan di situs adalah batu-batu candi. Struktur batu yang masih in-tact tepat berada di tebing sungai dan pada saat pengukran diperoleh panjang sekitar 186 $\mathrm{cm}$ dan lebar $113 \mathrm{~cm}$ yang terdiri dari 3 lapis batu secara vertikal. Ukuran batu candi mempunyai panjang $37 \mathrm{~cm}$, lebar 14 $\mathrm{cm}$, dan tinggi $24 \mathrm{~cm}$.

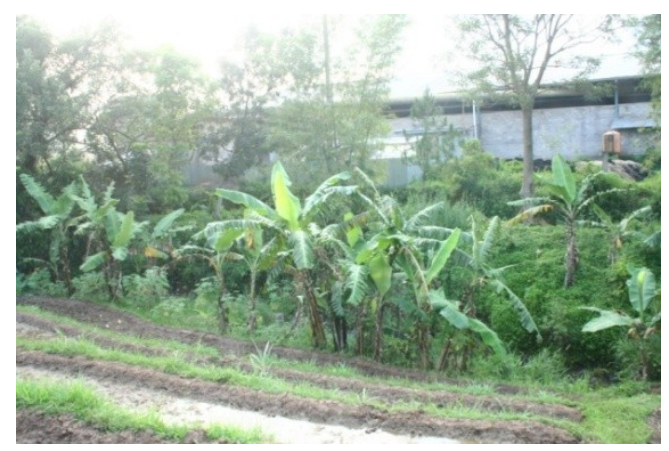

Foto 16. Lokasi Situs Randugunting

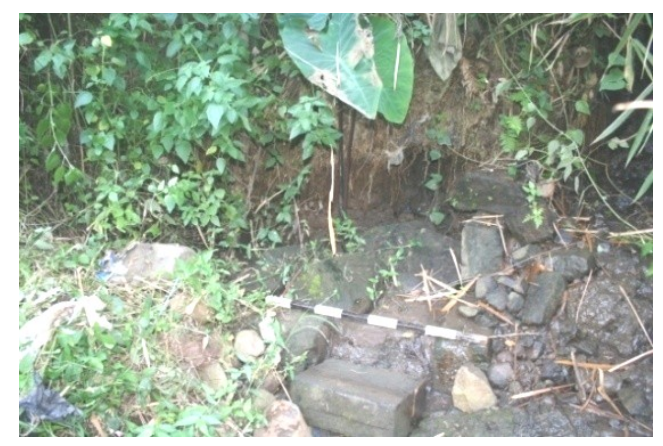

Foto 17. Batu-batu candi di Situs Randugunting 


\section{Situs Yoni Randugunting}

$\mathrm{Di}$ Desa Randugunting juga ditemukan objek data arkeologi berupa yoni, tepatnya di Dusun Krajan dengan koordinat S $07^{0} 12^{\prime} 53.8^{\prime \prime}$ dan E $110^{\circ} 25^{\prime}$ 52.0 " serta berada pada ketinggian 545 meter dari permukaan laut. Lokasi ini selanjutnya disebut dengan situs Yoni Randugunting. Yoni terbuat dari batu andesit dan kondisinya relatif masih utuh, kecuali pada bagian cerat yang sudah rusak. Berikut adalah ukuran yoni. Tinggi $49 \mathrm{~cm}$, lebar sisi bawah $70 \times 70 \mathrm{~cm}$, lebar sisi atas $67 \times 66 \mathrm{~cm}$, tempat lingga berukuran $11 \times 11 \mathrm{~cm}$ dengan kedalaman $25 \mathrm{~cm}$. Bagian cerat mempunyai panjang $13 \mathrm{~cm}$

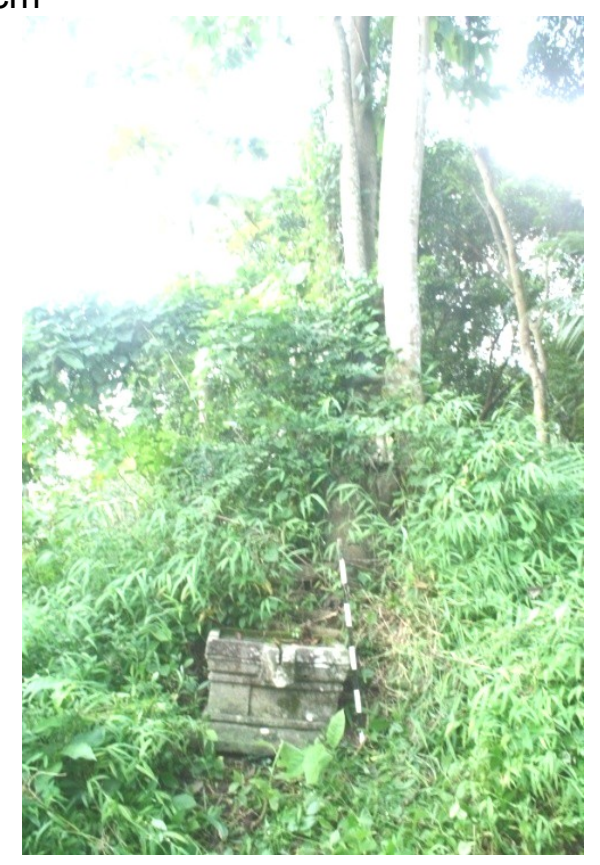

Foto 18. Yoni Randugunting

\section{Situs Wujil}

Situs Wujil terletak di Dusun Kalitaman, Desa Wujil, Kecamatan Bergas dengan koordinat $S 07^{0} 10^{\prime} 53.0$ " dan E $110^{\circ} 24^{\prime} 35.2^{\prime \prime}$ serta elevasi 566 meter dari permukaan laut. Objek arkeologi yang ditemukan meliputi calon yoni, calon kala ambang pintu, dan batu-batu candi. Lokasi Situs Wujil berada di atas Bukit Kalitaman, yang untuk mencapai lokasi situs ini harus melalui jalanan menanjak, serta kawasan hutan bambu. Di lokasi Situs Wujil ini dijumpai beberapa batu-batu candi berbagai bentuk dan ukuran serta calon yoni yang merupakan sebuah komponen dari bangunan candi. Sebagian besar batu- batu tertutup oleh lebatnya tanaman perdu dan alang-alang sehingga sulit untuk melakukan pencarian batu-batu candi di sekitar situs.

Yang menarik pada Situs Wujil ini adalah hampir sebagian besar batu-batu candi yang ditemukan belum selesai dikerjakan (unfinished) bahkan dijumpai sebuah monolit yang sudah dipahat untuk batu candi. Berikut deskripsi beberapa batu candi tersebut:

a. Calon Yoni (Unfinished Yoni). Terbuat dari andesit, kondisi masih utuh dan belum selesai dikerjakan (unfinished). Ukuran calon yoni ini mempunyai tinggi $82 \mathrm{~cm}$, lebar sisi atas $70 \times 70$ $\mathrm{cm}$, lebar sisi bawah $90 \times 90 \mathrm{~cm}$. Bagian cerat mempunyai panjang 29 $\mathrm{cm}$ dan lebar $30 \mathrm{~cm}$.

b. Calon Kala Ambang Pintu (Unfinished Kala). Terbuat dari andesit dan kondisi belum selesai dikerjakan. Calon kala ambang pintu mempunyai panjang $205 \mathrm{~cm}$, lebar $53 \mathrm{~cm}$, dan tinggi $46 \mathrm{~cm}$.

c. Alas kemuncak. Berjumlah empat buah dengan ukuran yang berbeda yang terbuat dari andesit. Kondisi alas kemuncak masih utuh dan sudah jadi. Secara umum ukuran alas kemuncak yaitu tinggi antara $20-52 \mathrm{~cm}$, lebar sisi bawah antara $67 \times 67 \mathrm{~cm}-109 \times$ $109 \mathrm{~cm}$.

d. Balok batu Candi. Kondisi masih utuh dan selesai dikerjakan. Ukuran batu candi mempunyai panjang $96 \mathrm{~cm}$, lebar $50 \mathrm{~cm}$, tinggi $20 \mathrm{~cm}$

e. Monolit. Berupa monolit yang berbentuk masif dan pahatan yang belum selesai, diduga monolit ini akan dibuat untuk batu candi. Ukuran monolit mempunyai panjang $280 \mathrm{~cm}$, lebar $220 \mathrm{~cm}$, dan tebal $26 \mathrm{~cm}$

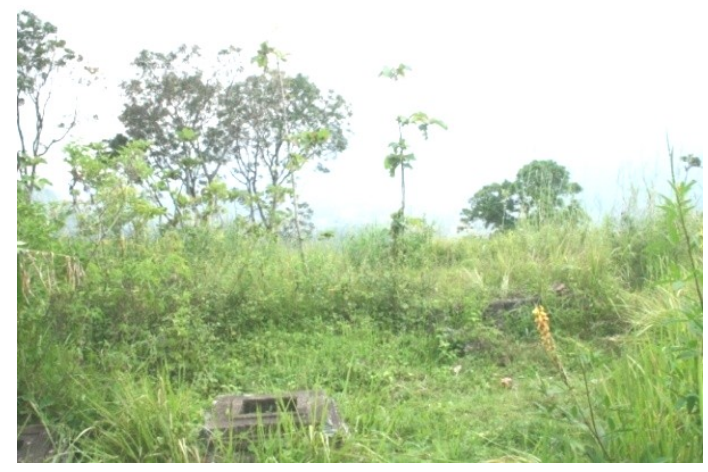

Foto 19. Lokasi Situs Wujil 


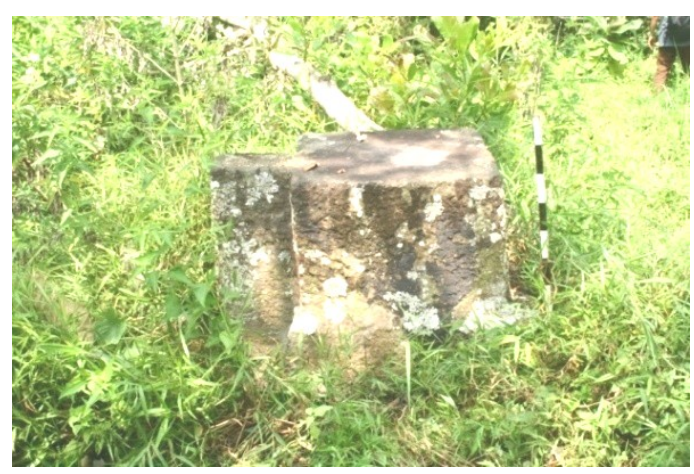

Foto 20. Calon Yoni di Situs Wujil

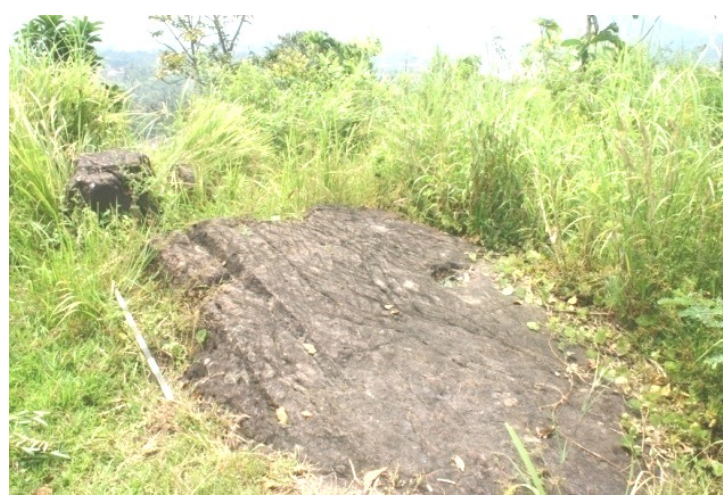

Foto 21. Monolit sebagai bakal batu candi

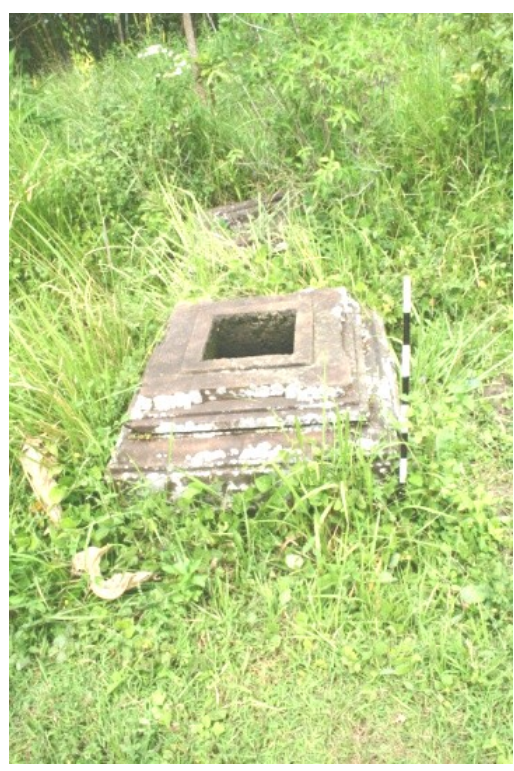

Foto 22. Alas kemuncak

\section{Situs Kuntobimo}

Nama Kuntobimo diberikan pada lokasi ini oleh penduduk Dusun Bantir, Desa Losari, Kecamatan Sumowono. Secara astronomis lokasi ini berada pada S $07^{\circ} 12^{\prime} 25,0^{\prime \prime}$ dan E $110^{\circ} 18^{\prime} 48,4^{\prime \prime}$ serta elevasi 1011 meter dpl. Objek arkeologi yang ditemukan berupa sebuah lingga yang terletak di dalam cungkup di area pemakaman umum Desa Losari. Kondisi lingga tidak utuh karena patah di bagian tengah. Ukuran objek adalah, tinggi 84, penampang atas $24 \times 24$, tinggi penampang 29, dan diameter $27 \mathrm{~cm}$.

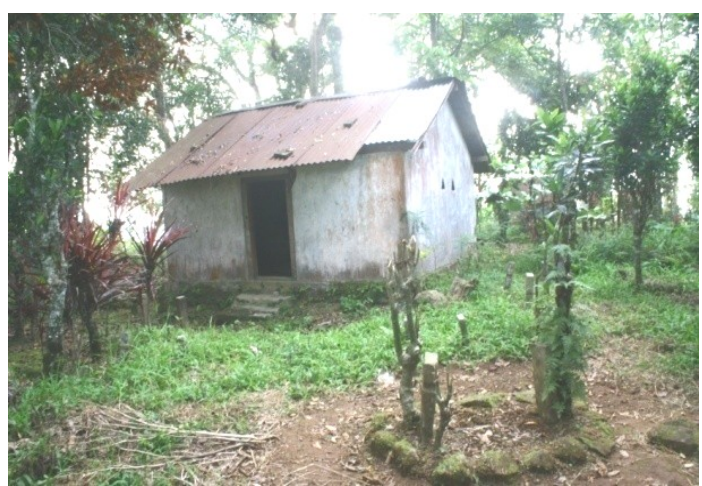

Foto 23. Cungkup lokasi Lingga berada

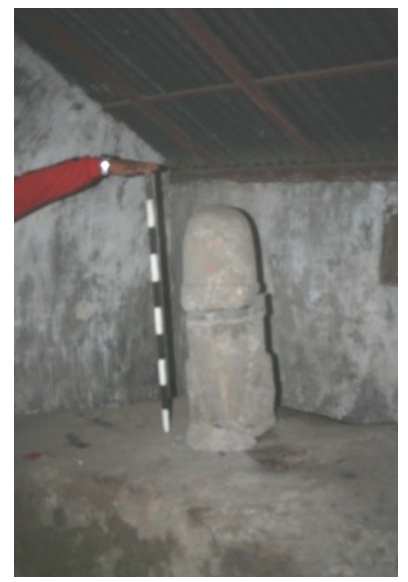

Foto 24. Lingga dari Situs Kuntobimo

\section{Situs Cebur}

Situs Cebur secara administratif termasuk di dalam wilayah Dusun Cebur, Desa Kalibeji, Kecamatan Tuntang dengan koordinat S $07^{0} 19^{\prime} 36.4^{\prime \prime}$ dan E $110^{\circ} 26^{\prime}$ 59.8" serta elevasi 504 meter dpl. Objek arkeologi yang dijumpai adalah yoni, kemuncak, batu candi, dan lingga patok.

Berikut deskripsi objek arkeologi yang ditemukan di situs Cebur.

a. Yoni. Berbahan batu andesit dengan kondisi relatif utuh. Berukuran tinggi $77 \mathrm{~cm}$, penampang sisi atas dan bawah $90 \times 90 \mathrm{~cm}$, lubang tengah berbentuk segi empat $27 \times 27 \mathrm{~cm}$, kedalaman lubang $55 \mathrm{~cm}$. Cerat mempunyai panjang $32 \mathrm{~cm}$, lebar bagian dalam $29 \mathrm{~cm}$, lebar ujung 22 
$\mathrm{cm}$. Tinggi ujung cerat $17 \mathrm{~cm}$. Di bawah cerat terdapat kura-kura yang berukuran tinggi $7.5 \mathrm{~cm}$ dan di bawahnya terdapat naga dengan ukuran tinggi $45 \mathrm{~cm}$. Masyarakat setempat menyebut yoni ini sebagai watu gentong.

b. Kemuncak Candi. Berbahan batu andesit yang berjumlah tiga buah. Kemuncak terbesar berukuran tinggi $48 \mathrm{~cm}$, penampang atas $29 \times 29 \mathrm{~cm}$, penampang bawah $32 \times 59 \mathrm{~cm}$. Keberadaan tiga buah kemuncak ini masih satu lokasi dengan yoni.

c. Batu candi. Berbahan batu andesit yang berjumlah satu buah. Keberadaan batu candi ini berada di bawah ketiga kemuncak. Seperti kemuncak candi, lokasi batu candi ini berada di lokasi yoni

d. Kumpulan Batu candi. Terletak di sebelah utara 50 meter dari lokasi Yoni. Kumpulan batu candi ini berasal dari sekitar lokasi Dusun Cebur yang kemudian disusun kembali untuk dimanfaatkan sebagai nisan yang tidak permanen.

e. Lingga Patok. Berbahan batu andesit dan kondisi relatif utuh namun bagian dasarnya sudah disemen. Lingga ini berada di tepi jalan dusun Cebur yaitu pada posisi S $07^{\circ} 19^{\prime} 48.0^{\prime \prime}$ E $110^{\circ} 27^{\prime}$ 04.7". Lingga ini berukuran tinggi 70 $\mathrm{cm}$, penampang bawah $26 \times 23 \mathrm{~cm}$. Berdasarkan informasi dari Bapak Jito
(Kadus Cebur) bahwa disekitar dusun Cebur selain temuan arkeologi tersebut di atas masih dijumpai temuan lainnya seperti lingga patok, arca Nandi, serta yoni. Narasumber juga memberikan informasi bahwa di wilayah Dusun Cebur juga dijumpai sebuah gumuk dengan beberapa batu candi di sekitarnya.

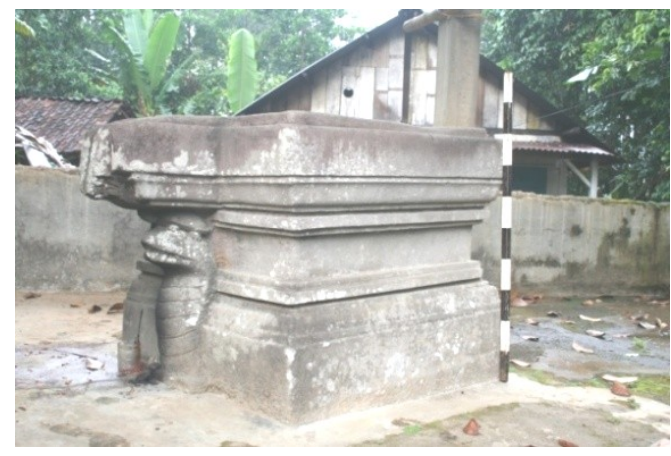

Foto 25. Yoni dari Situs Cebur

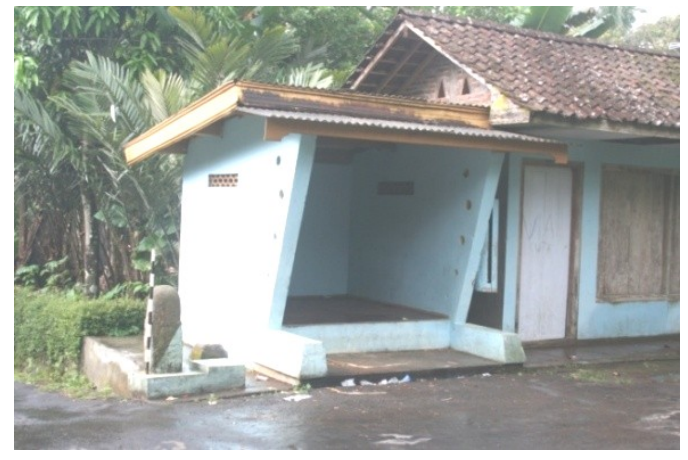

Foto 26. Lokasi Lingga Patok 


\section{Bentuk Data Arkeologi}

Secara umum, rekapitulasi hasil penelitian dapat dilihat pada tabel berikut ini.

Tabel 1. Rekapitulasi Hasil Survei

\begin{tabular}{|c|c|c|c|c|c|c|}
\hline NO & SITUS & OBJEK & E. & S. & ELEV. & KEC. \\
\hline 1 & Yoni Kerep & Yoni & $110^{0} 23$ '55.1" & $07^{0} 15^{\prime} 12.5^{\prime \prime}$ & 584 & Ambarawa \\
\hline 2 & Banyukuning & $\begin{array}{c}\text { Jambangan } \\
\text { Batu }\end{array}$ & $110^{0} 20^{\prime} 38.9^{\prime \prime}$ & $07^{0} 14^{\prime} 19.6 "$ & 912 & Bandungan \\
\hline 3 & Candi Asu & $\begin{array}{c}\text { Yoni, } \\
\text { makara, } \\
\text { kemuncak, } \\
\text { alas } \\
\text { kemuncak }\end{array}$ & $110^{\circ} 20^{\prime} 29.2 "$ & $07^{0} 13^{\prime} 25.9^{\prime \prime}$ & 1055 & Bandungan \\
\hline 4 & $\begin{array}{c}\text { Yoni } \\
\text { Nglarangan }\end{array}$ & $\begin{array}{l}\text { Yoni, kala, } \\
\text { umpak, alas } \\
\text { kemuncak }\end{array}$ & $110^{\circ} 20^{\prime} 34.6 "$ & $07^{0} 13^{\prime} 06.3^{\prime \prime}$ & 1137 & Bandungan \\
\hline 5 & $\begin{array}{l}\text { Umbul } \\
\text { Sidomukti }\end{array}$ & $\begin{array}{l}\text { Durga, } \\
\text { jaladwara, } \\
\text { batu-batu } \\
\text { candi }\end{array}$ & $110^{\circ} 22^{\prime} 27.3^{\prime \prime}$ & $07^{0} 11^{\prime} 41.2 "$ & 1046 & Bandungan \\
\hline 6 & $\begin{array}{l}\text { Lingga Yoni } \\
\text { Pentasan }\end{array}$ & $\begin{array}{l}\text { Lingga, yoni, } \\
\text { umpak }\end{array}$ & $110^{\circ} 25^{\prime} 21.7^{\prime \prime}$ & $07^{0} 18^{\prime} 24.7^{\prime \prime}$ & 495 & Banyubiru \\
\hline 7 & Yoni Muncul & $\begin{array}{c}\text { yoni, } \\
\text { fragmen arca } \\
\text { siwa } \\
\text { mahaguru }\end{array}$ & $110^{\circ} 26^{\prime} 24.9^{\prime \prime}$ & $07^{0} 10^{\prime} 42.9^{\prime \prime}$ & 495 & Banyubiru \\
\hline 8 & Randugunting & $\begin{array}{l}\text { batu-batu } \\
\text { candi }\end{array}$ & $110^{\circ} 25^{\prime} 38.7^{\prime \prime}$ & $07^{0} 12^{\prime} 48.3^{\prime \prime}$ & 513 & Bergas \\
\hline 9 & $\begin{array}{c}\text { Yoni } \\
\text { Randugunting }\end{array}$ & Yoni & $110^{\circ} 25^{\prime} 52.0^{\prime \prime}$ & $07^{0} 12^{\prime} 53.8^{\prime \prime}$ & 545 & Bergas \\
\hline 10 & Wujil & $\begin{array}{l}\text { Komponen } \\
\text { Candi }\end{array}$ & $110^{\circ} 24^{\prime} 35.2^{\prime \prime}$ & $07^{0} 10^{\prime} 53.0^{\prime \prime}$ & 566 & Bergas \\
\hline 11 & Kuntobimo & Lingga & $110^{\circ} 18^{\prime} 48.4^{\prime \prime}$ & $07^{0} 12^{\prime} 25.0^{\prime \prime}$ & 1011 & Sumowono \\
\hline 12 & Cebur & $\begin{array}{c}\text { Yoni, Lingga } \\
\text { Patok, batu- } \\
\text { batu candi }\end{array}$ & $110^{\circ} 26^{\prime} 59.8^{\prime \prime}$ & $07^{0} 19^{\prime} 36.4^{\prime \prime}$ & 504 & Tuntang \\
\hline
\end{tabular}

Berdasarkan kompleksitas data, terdapat tiga situs berupa data tunggal dan sembilan situs memiliki benda arkeologi yang kompleks. Khusus untuk situs dengan data arkeologi yang kompleks dapat dibedakan menjadi dua, yaitu situs dengan data arkeologi yang menunjuk pada komponen bangunan candi, serta situs yang tidak menunjuk pada bangunan candi.
Situs dengan data tunggal adalah situs Yoni Kerep dengan benda arkeologi berupa sebuah yoni; situs Yoni Randugunting berupa sebuah yoni, dan situs Kuntobimo dengan benda arkeologi berupa sebuah lingga. Situs dengan data arkeologi yang kompleks dan memiliki petunjuk kuat sebagai sebuah bangunan candi adalah situs Candi Asu dengan benda arkeologi berupa makara, kemuncak, dan alas kemuncak; situs Yoni 
Nglarangan yang ditunjukkan oleh adanya kala, kemuncak, dan alas kemuncak; situs Umbul Sidomukti yang memiliki komponen bangunan candi berupa jaladwara dan batu-batu candi; situs Randugunting berupa batu-batu candi; situs Wujil yang di dalamnya terdapat komponen-komponen bangunan candi dan sebagian diduga belum selesai dikerjakan; dan situs Cebur yang antara lain memiliki data arkeologi berupa patok batu dan batu-batu candi. Situs yang memiliki data arkeologi lebih dari satu tetapi tidak menunjuk pada bangunan candi adalah situs Banyukuning dengan dua buah jambangan batu; situs Pentasan dengan data arkeologi berupa sebuah lingga dan sebuah yoni; dan situs
Muncul yang di dalamnya terdapat sebuah yoni dan fragmen arca.

\section{Sebaran Data Arkeologi}

Sebaran data arkeologi dalam hal ini menujuk pada lokasi atau tempat ditemukanya benda arkeologi yang terbagi lokasi berdasarkan wilayah administrasi dan lokasi berdasarkan konteks lingkungan. Berdasarkan wilayah administrasi dalam hal mencakup enam kecamatan, yaitu Kecamatan Ambarawa, Bandungan, Banyubiru, Bergas, Sumowono, dan Kecamatan Tuntang. Selengkapnya sebaran situs dan benda arkeologi hasil survei dipaparkan dalam tabel berikut

Tabel 2. Sebaran Data Arkeologi Berdasarkan Wilayah Kecamatan

\begin{tabular}{|c|c|c|c|}
\hline NO & KECAMATAN & SITUS & OBJEK \\
\hline 1 & Ambarawa & Yoni Kerep & Yoni \\
\hline 2 & Bandungan & Banyukuning & Jambangan Batu \\
\hline 3 & Bandungan & Candi Asu & $\begin{array}{c}\text { Yoni, makara, kemuncak, alas } \\
\text { kemuncak }\end{array}$ \\
\hline 4 & Bandungan & Yoni Nglarangan & Yoni, kala, umpak, alas kemuncak \\
\hline 5 & Bandungan & Umbul Sidomukti & Durga, jaladwara, batu-batu candi \\
\hline 6 & Banyubiru & $\begin{array}{c}\text { Lingga Yoni } \\
\text { Pentasan }\end{array}$ & Lingga, yoni, umpak \\
\hline 7 & Banyubiru & Yoni Muncul & yoni, fragmen arca siwa mahaguru \\
\hline 8 & Bergas & Randugunting & batu-batu candi \\
\hline 9 & Bergas & Yoni Randugunting & Yoni \\
\hline 10 & Bergas & Wujil & Komponen Candi \\
\hline 11 & Sumowono & Kuntobimo & Lingga \\
\hline 12 & Tuntang & Cebur & Yoni, Lingga Patok, batu-batu candi \\
\hline
\end{tabular}


Dari tabel tersebut tampak bahwa dari 12 situs dan benda arkeologi hasil survei, empat di antaranya terdapat di Kecamatan Bandungan, tiga di Kecamatan Bergas, dua di Kecamatan Banyubiru, dan masing-masing satu lokasi di Kecamatan Ambarawa, Sumowono, dan Tuntang.

Distribusi atau sebaran data arkeologi berdasarkan konteks lingkungan dalam hal ini menjadi penting mengingat hubungan benda arkeologi dengan lingkunganya merupakan salah satu perhatian dalam kajian arkeologi arkeologi masa klasik di Kabupaten Semarang juga dapat dijelaskan keberadaannya dalam kaitannya dengan konteks lingkungan. sebagaimana terlihat pada peta berikut ini.

Berdasarkan Peta 1 tampak bahwa konteks lingkungan, dalam hal ini bentang lahan, data arkeologi hasil survei terletak pada bentang lahan yang berbeda. Setidaknya konteks lingkungan tersebut meliputi tiga bentang lahan, yaitu 1) lereng dan kaki pegunungan Ungaran, 2) dataran di dekat kaki Pegunungan Ungaran, dan 3) tepian Rawa Pening.

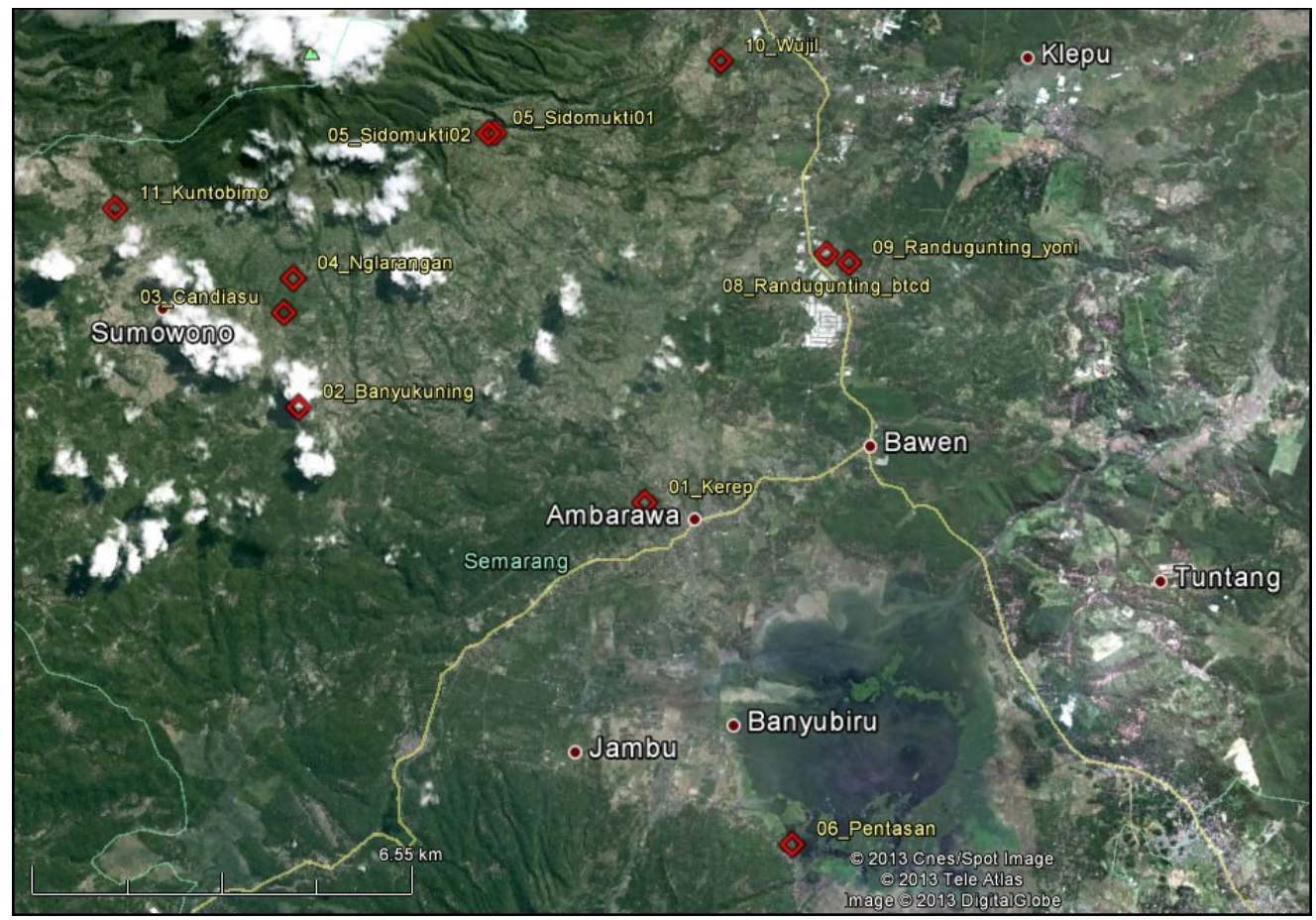

Peta 1. Gambaran umum sebaran data arkeologi hasil survei

ruang (Mundardjito, 2002: 73). Setidaknya informasi tentang konteks bentang lahan suatu situs atau benda arkeologi harus dapat dijelaskan sebagai konteks lingkungannya. Pada prinsipnya, suatu bentang lahan yang di dalamnya terdapat unit-unit bentuk lahan (landforms) adalah dasar dari lingkungan manusia dengan berbagai keseragaman dan keragaman unsur-unsurnya (Yuwono, 2007). Demikian pula dengan sebaran data
Gambaran distribusi berdasarkan konteks bentang lahan tersebut dapat dilihat pada peta berikut ini.

Kelompok 1 di lereng dan kaki Pegunungan Ungaran meliputi situs Banyukuning, Candi Asu, Nglarangan, Sidomukti, Wujil, dan situs Kuntobimo. Kelompok 2 di dataran dekat kaki Pegunungan Ungaran meliputi situs yoni Randugunting, dan batu candi 
Randugunting. Kelompok 3 di tepian

sebagian tepian Rawa Pening Rawa Pening terdapat situs Pentasan. merupakan daerah integral dari

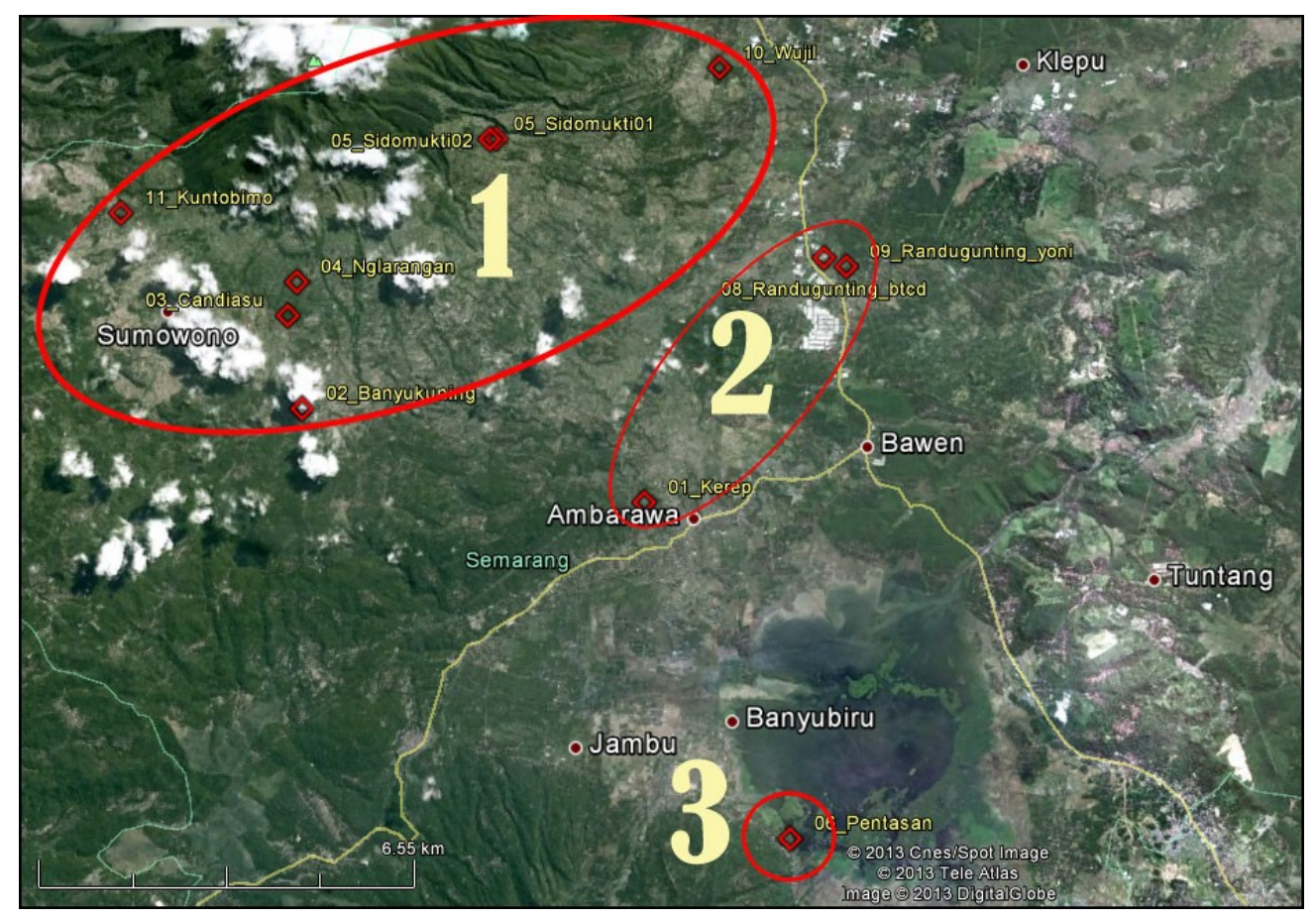

Peta 2. Kelompok sebaran data arkeologi hasil survei di Kabupaten Semarang

\section{PENUTUP}

Hingga saat ini Kabupaten Semarang ditempatkan sebagai wilayah yang berada di luar poros KeduPrambanan sebagai wilayah kekuasaan Mataram Kuna adalah benar adanya jika dilihat dari aspek geografis maupun administratif. Keberadaan data arkeologi di Kabupaten Semarang, berupa situs dan benda-benda arkeologi, ternyata tidak sekedar Gedongsongo dan Candi Ngempon, atau setidaknya Candi Dukuh di tepian Rawa Pening. Hasil survei menunjukkan adanya 12 "situs tersembunyi" yang secara kronologis diyakini berasal dari masa Mataram Kuna. Berdasarkan bentuk data dan sebarannya, keduabelas situs dan benda arkeologi masa klasik tersebut mengisyaratkan adanya berbagai potensi, diantaranya:

a. Wilayah Kabupaten Semarang, khususnya lereng dan kaki Pegunungan Ungaran hingga kekuasaan Mataram Kuna

b. Sangat mungkin akan ditemukan situs-situs dari masa Mataram Kuna lainnya mengingat situs hasil survei maupun situs yang sudah ditemukan sebelumnya memiliki sebaran yang cukup luas dengan konteks lingkungan yang cukup beragam

c. Beberapa situs memerlukan pendalaman penelitian, khususnya melalui ekskavasi, berdasarkan ragam benda arkeologi yang ditemukan, yaitu situs Candi Asu, Nglarangan, Sidomukti, Wujil, dan situs Cebur.

Berdasarkan hal itu, maka kajian kewilayahan dalam arkeologi masa klasik perlu dikembangkan secara horisontal, setidaknya hingga Kabupaten Semarang, meskipun pijakan awalnya dapat berasal dari poros Kedu-Prambanan. Untuk mengungkap situs-situs yang lain yang sangat mungkin masih "tersembunyi" jelas masih diperlukan kegiatan eksplorasi yang secara khusus ditujukan 
untuk menemukan situs atau bendabenda arkeologi masa klasik di Kabupaten Semarang. Hal ini dapat dilakukan baik dengan eksplorasi kepustakaan maupun observasi langsung di lapangan, atau bahkan gabungan antara keduanya. Satu hal yang patut mendapat perhatian sebagai salah satu tindak lanjut dari hasil survei ini adalah kegiatan pendalaman penelitian di situs Candi Asu, Nglarangan, Sidomukti, Wujil, dan situs Cebur. 


\section{DAFTAR PUSTAKA}

Azwar, Saifuddin. 1998. Metode Penelitian. Yogyakarta: Pustaka Pelajar.

Bosch, F.D.K. 1974. Masalah Penyebaran Kebudayaan Hindu di Kepulauan Indonesia, terj. LIPI-KITLV. Jakarta: Bhratara.

Danim, Sudarwan. 2002. Menjadi Peneliti Kualitatif. Bandung: Pustaka Setia.

Haryono, Timbul. 1993. "Metodologi dan Aplikasinya dalam Penelitian Arkeologi" dalam Artefak No. 13. HIm. 9-14.

Mundardjito. 2002. "Arkeologi Keruangan: Konsep dan Cara Kerjanya" dalam Kumpulan Makalah Pertemuan IImiah Arkeologi VII. Jakarta: Ikatan Ahli Arkeologi Indonesia. HIm. 70-75.

Riyanto, Sugeng, 2012. "Eksplorasi Situs dan Cagar Budaya di Kabupaten Semarang dan Sekitarnya, Jawa Tengah". Laporan Penelitian. Tidak terbit.

Satari, Sri Soejatmi. 2002. "Penyerapan dan Pemanfaatan Aspek Budaya Hindu-Buddha dalam Masyarakat Masa Kini" dalam Kumpulan Makalah Pertemuan IImiah Arkeologi VII. Jakarta: Ikatan Ahli Arkeologi Indonesia. HIm. 61-63.

Sumanto. 1995. Metodologi Penelitian Sosial dan Pendidikan. Yogyakarta: Penerbit Andi Offset.

Yuwono, J. Susetyo Edy. 2007. "Kontribusi Sistem Informasi Geografis dalam Berbagai Skala Kajian Arkeologi Lansekap" dalam Berkala Arkeologi Tahun XXVII No. 2. Yogyakarta: Balai Arkeologi Yogyakarta. HIm. 81-102. 
